\title{
Signalling through neutrophil Fc $\gamma$ RIII, Fc $\gamma$ RII, and CD59 is not impaired in active rheumatoid arthritis
}

\author{
Jane Jones, Iraj Laffafian, Tom Lawson, Bryan D Williams, B Paul Morgan
}

\begin{abstract}
Objective-To compare neutrophil Fc receptor (FcyR) and CD59 signalling responses in normal healthy subjects and patients with active rheumatoid arthritis (RA).

Methods-Intracellular free calcium concentrations were measured in neutrophils loaded with the fluorescent calcium indicator fura-2, using a spectrofluorimeter.

Results-Basal intracellular calcium ion concentrations were similar in both groups when no primary antibody, CD59, or CD32 (FcyRII) antibody was added. When CD16 (FcyRIII) antibody was added, there was a significantly greater basal calcium concentration in the patient group compared with the control group. Transient cytosolic calcium ion fluxes were observed after binding FcyRII, FcyRIII, or CD59 with specific monoclonal antibodies and cross linking with the $F(a b)_{2}$ fragment of sheep antimouse IgG. Peak concentrations of intracellular free calcium, $\left[\mathrm{Ca}^{2+}\right]_{i}$, after cross linking each of the three receptors, were comparable between normal healthy donors and patients with RA. The lag period between addition of cross linking antibodies and the increase in calcium was also similar between normal individuals and patients.
\end{abstract}

Conclusion-Contrary to previous reports, these results demonstrate that $\mathrm{Ca}^{2+}$ signalling responses of cross linked Fc receptors in blood neutrophils from patients with RA are identical to those in neutrophils of normal subjects. Signalling responses of cross linked CD59 are also unaltered.

Department of Medical Biochemistry, University of Wales College of Medicine, Heath Park, Cardifi CF4 4XN, United Kingdom J Jones

I Laffafian

B P Morgan

Department of Rheumatology T Lawson

B D Williams

Correspondence to: Dr J Jones.

Accepted for publication 30 January 1996
(Ann Rheum Dis 1996; 55: 294-297)

Neutrophils are the predominant cell type found in the synovial fluid of patients with rheumatoid arthritis (RA). They have a central role in the development and progression of the disease, and their survival in an environment where complement activation is taking place is an important issue. We are interested in the expression and function of the complement inhibitory molecules, particularly CD59, on neutrophils. This molecule, attached to the membrane by a glycosyl phosphatidylinositol (GPI) anchor, ${ }^{1}$ can trigger neutrophil activation when cross linked. ${ }^{2}{ }^{3}$ Neutrophil acti- vation through cross linking of another GPI anchored molecule, CD16-the Fc $\gamma$ receptor III (FcyRIII)-has also been reported recently. ${ }^{4-7}$ There is conflicting evidence as to whether blood neutrophil functions are defective in RA. ${ }^{8}$ It has been reported recently that signalling through neutrophil $\mathrm{Fc} \gamma \mathrm{R}$ is impaired in active $R A$, which could reflect a receptor signalling defect with potential effects on Fc mediated functions, or a fundamental defect in calcium ion homeostasis within these cells. ${ }^{9}$ The implications of this report led us to examine whether signalling via CD59 was also impaired in blood neutrophils from patients with active RA, and to re-examine the putative defect in FcyR signalling using a sensitive method for measuring calcium signalling.

\section{Patients and methods \\ PATIENTS}

Peripheral blood $(20 \mathrm{ml})$ was obtained from eight normal healthy donors and eight patients with RA. The eight patients were classified as having active RA with synovitis, nine or more swollen joints, and an erythrocyte sedimentation rate $>35 \mathrm{~mm} / 1 \mathrm{st} \mathrm{h}$. The median and range of age in the control and patient groups were $42(24-55)$ years and 60 (45-75) years, respectively.

PREPARATION OF NEUTROPHILS

Blood from donors was collected into heparinised universal containers. Neutrophils were isolated essentially as described previously. ${ }^{10}$ Briefly, leucocytes were separated from erythrocytes by dextran sedimentation using $0.6 \% \quad \mathrm{w} / \mathrm{v}$ dextran (Fisons, Loughborough, UK). The leucocyte rich upper layer was then fractionated by layering on Histopaque (Sigma, Poole, Dorset, UK) followed by centrifugation at $220 \mathrm{~g}$ for 25 minutes. Residual erythrocytes in the polymorphonuclear rich cell pellet were removed by hypotonic lysis. All these procedures were carried out at ambient temperature. Cell viability, assessed by exclusion of the vital stain trypan blue, showed that the cells were greater than $95 \%$ viable. Microscopy showed less than $5 \%$ contamination by mononuclear cells. After purification, the neutrophils were suspended in Krebs-HEPES buffer containing ( $\mathrm{mmol} / \mathrm{l})$ : sodium chloride 120; potassium chloride 4.8; monobasic potassium phosphate $1 \cdot 2$; calcium chloride 1.3 ; magnesium sulphate 
1.2; ( $N$-2-hydroxyethylpiperazine- $N$-2-ethanesulphonic acid) (HEPES) 25.

ANTIBODIES

FcyRIII antibody (CD16; MEM-154, IgG1 isotype) was a kind gift from Dr Vaclav Horejsi, Academy of Sciences of the Czech Republic, Prague. CD59 antibody (BRIC 229, IgG2b isotype) was obtained from the International Blood Group Reference Laboratory, Elstree, Herts, UK. FcyRII antibody (CD32; AT10, IgGl isotype) was from Dr Martin Glennie, Tenovus, Southampton, UK. Polyclonal antimouse IgG was raised in sheep, the IgG
NORMAL
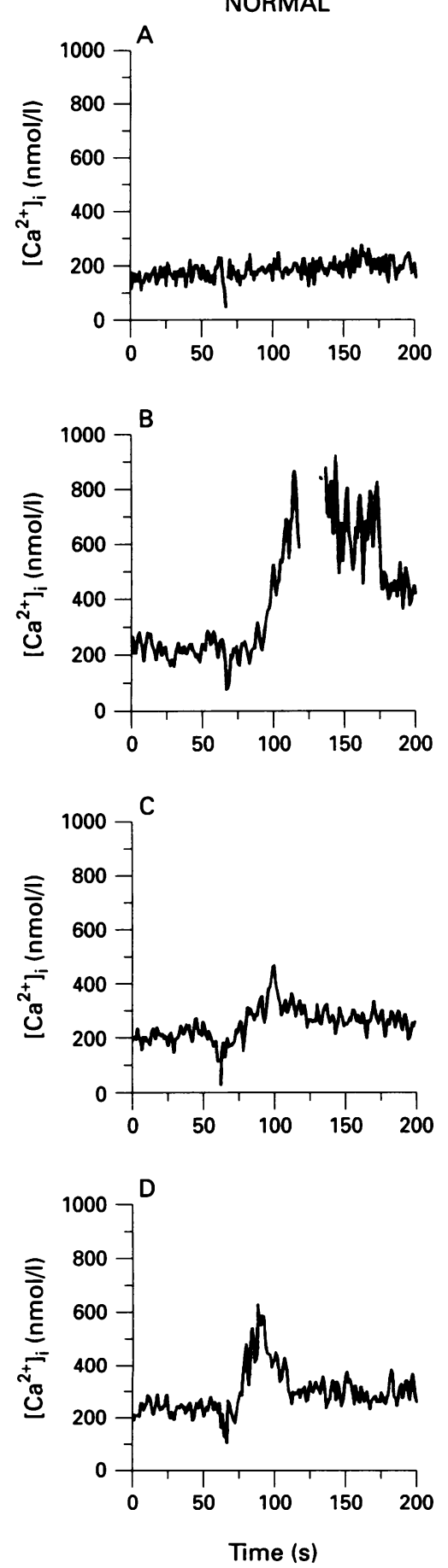

RA
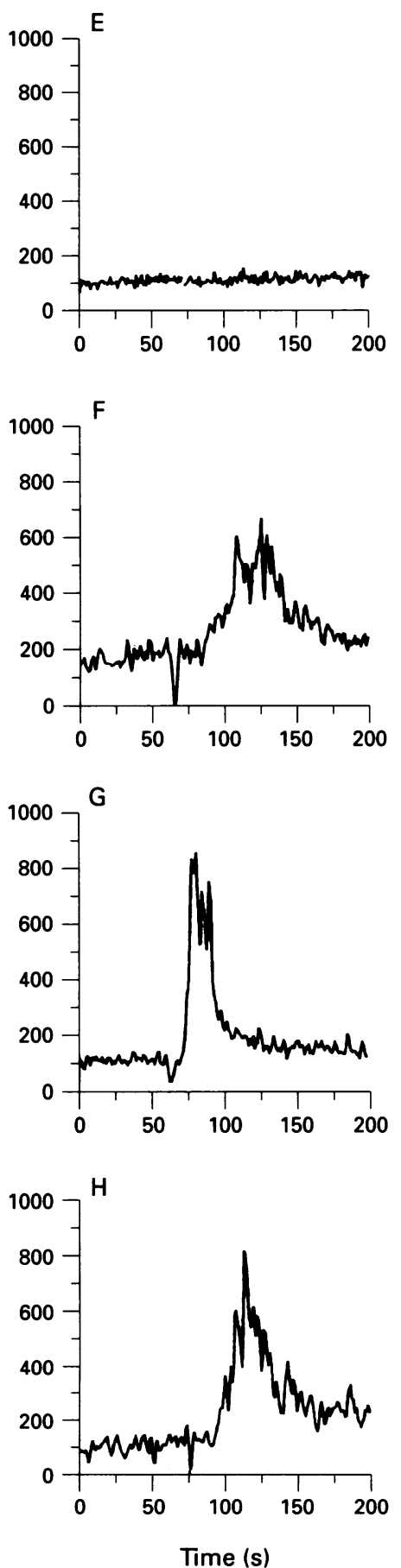

Figure 1 Calcium ion fluxes in neutrophils isolated from a normal donor $(\boldsymbol{A}-\boldsymbol{D})$ and a patient with active $R A(\boldsymbol{E}-\boldsymbol{H})$ in response to cross linking. $\boldsymbol{A}, \boldsymbol{E}:$ No primary antibody; B, F: FcyRIII; C, G: CD59; D, H: FcyRII. The cross linking second antibody (sheep antimouse $\left.\operatorname{Ig} G F(a b)_{2}\right)$ was added at 60 seconds. fraction purified, and $F(a b)_{2}$ fragments prepared by standard methods.

ANALYTICAL METHODS

Intracellular calcium ion concentrations $\left(\left[\mathrm{Ca}^{2+}\right]_{\mathrm{i}}\right)$ were measured using the fluorescent calcium binding probe, fura-2 (Molecular Probes, Junction City, Oregon). Population studies were performed rather than single cell studies, for ease of experimentation and in order to allow correlation with the results of Goulding and Guyre. ${ }^{9}$ Neutrophils $\left(1 \times 10^{7}-1 \times 10^{8} / \mathrm{ml}\right)$ were incubated with fura- 2 acetoxymethyl ester (final concentration $1 \mu \mathrm{mol} / \mathrm{l}$ ) for 30 minutes at ambient temperature in Krebs-HEPES buffer containing $0 \cdot 1 \%$ bovine serum albumin. After loading, the cells were washed once then resuspended at $5 \times 10^{6} / \mathrm{ml}$ in the same medium. The cells were incubated with primary antibody (CD16, CD32, or CD59 at a final concentration of $20 \mu \mathrm{g} / \mathrm{ml}$ ) for 30 minutes on ice. The cells were washed twice with Krebs-HEPES buffer and kept on ice. Cells $\left(200 \mu \mathrm{l}, 1 \times 10^{6}\right)$ were added to $2 \mathrm{ml}$ Krebs-HEPES buffer prewarmed to $37^{\circ} \mathrm{C}$ and placed in a stirred quartz fluorimeter cuvette in a dual wavelength fluorimeter (Spex II fluorolog system, Glen Spectra, Stanmore, Middx, UK) with the temperature set at $37^{\circ} \mathrm{C}$. Simultaneous excitation at $340 \mathrm{~nm}$ and $380 \mathrm{~nm}$ was achieved using two lamps and monochromators together with a mirrored chopper system. Fluorescence emission was detected at $505 \mathrm{~nm}$. Basal fluorescence was monitored for one minute before primary antibodies were cross linked by the addition of $\mathrm{F}(\mathrm{ab})_{2}$ fragment of sheep antimouse IgG (final concentration $60 \mu \mathrm{g} / \mathrm{ml}$ ). The fluorescence intensity of emission was measured for a further four minutes. After completion of the measurements, digitonin ( $50 \mu \mathrm{mol} / \mathrm{l}$ final concentration) followed by EGTA $(20 \mathrm{mmol} / \mathrm{h}$ final concentration) were added to the cuvette to provide $\mathrm{Ca}^{2+}$ bound ( $R$ max) and $\mathrm{Ca}^{2+}$ free (Rmin) signals, respectively. The ratio $(R)$ of the fluorescent intensities at $340 \mathrm{~nm}$ and $380 \mathrm{~nm}$ is related to $\mathrm{Ca}^{2+}$ concentration by the equation:

$$
\mathrm{Ca}^{2+}=K(R-R \min ) /(R \max -R)
$$

where $K=0.2865 \mu \mathrm{mol} / 1 .^{11}$

STATISTICAL ANALYSIS

Parameters were compared between normal subjects and patients and the significance of differences expressed using the Mann-Whitney $U$ test, assuming a non-parametric data distribution.

\section{Results}

Figure 1 shows representative $\mathrm{Ca}^{2+}$ fluxes triggered by cross linking the three different primary antibodies. For a few samples there were insufficient cells to obtain results for all antibodies, but results from a minimum of six samples were analysed per antibody per group.

Figure 2 shows two measurements summarising the data from each recorded trace for each subject. The basal value is the average $\left[\mathrm{Ca}^{2+}\right]_{\mathrm{i}}$ 

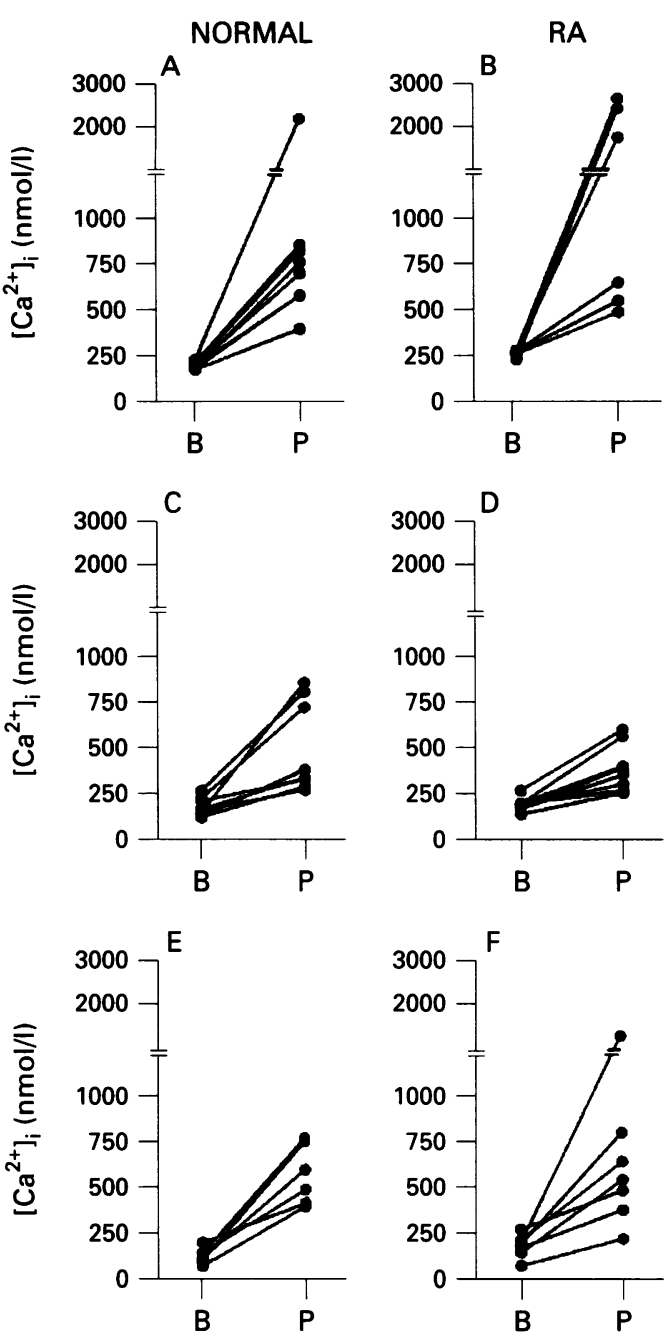

Figure 2 Neutrophil $\left[\mathrm{Ca}^{2+}\right]_{i}$ in normal control subjects $(\boldsymbol{A}$ $\boldsymbol{C}, \boldsymbol{E})$ and patients with $R A(\boldsymbol{B}, \boldsymbol{D}, \boldsymbol{F})$. Basal $(B)$ and peak $(P)\left[C a^{2+}\right]_{i}$ in cells preincubated with $C D 16(\boldsymbol{A}, \boldsymbol{B})$, CD59 $(C, D)$, or $C D 32(\boldsymbol{E}, \boldsymbol{F})$ antibodies and cross linked with sheep antimouse $\operatorname{Ig} G F(a b)_{2}$.

from three readings taken during the first 60 seconds of the trace before cross linking antibody was added. The peak $\left[\mathrm{Ca}^{2+}\right]_{\mathrm{i}}$ is the average of two readings taken at the height of the calcium response. The lag time, defined as the time interval between addition of the cross linking antibody and the start of any increase in calcium concentration, was also measured for each trace (table).

Incubation of fura-2 loaded cells with monoclonal antibodies to CD59 or CD32 had no effect on the basal $\left[\mathrm{Ca}^{2+}\right]_{\mathrm{i}}$ value in either group, compared with cells that had been incubated

Basal and peak $\left[\mathrm{Ca}^{2+}\right]_{i}$ and lag times in normal control subjects and patients with $R A$

\begin{tabular}{|c|c|c|c|c|c|c|}
\hline & \multicolumn{2}{|c|}{$\begin{array}{l}\text { Basal }\left[\mathrm{Ca}^{2+}\right]_{i} \\
\text { (nmoln) }\end{array}$} & \multicolumn{2}{|c|}{$\begin{array}{l}\text { Peak }\left[\mathrm{Ca}^{2+}\right]_{i} \\
(\text { nmoln })\end{array}$} & \multicolumn{2}{|l|}{$\begin{array}{l}\text { Lag } \\
\text { (seconds) }\end{array}$} \\
\hline & Normal & $R A$ & Normal & $R A$ & Normal & $R A$ \\
\hline Control & $\begin{array}{l}167 \cdot 1 \\
(69 \cdot 7) \\
n=8\end{array}$ & $\begin{array}{l}204 \cdot 8 \\
(49 \cdot 9) \\
\mathrm{n}=8\end{array}$ & - & - & - & - \\
\hline CD16 & $\begin{array}{l}186 \cdot 0 \\
(17 \cdot 8) \\
n=8\end{array}$ & $\begin{array}{l}254 \cdot 0^{\star} \\
(16 \cdot 6) \\
\mathrm{n}=6\end{array}$ & $\begin{array}{c}854 \cdot 4 \\
(558 \cdot 6)\end{array}$ & $\begin{array}{l}1408 \cdot 8 \\
(979 \cdot 2)\end{array}$ & $\begin{array}{c}35 \cdot 8 \\
(28 \cdot 4)\end{array}$ & $\begin{array}{l}30 \cdot 7 \\
(6 \cdot 1)\end{array}$ \\
\hline CD59 & $\begin{array}{l}153 \cdot 8 \\
(50.9) \\
n=8\end{array}$ & $\begin{array}{l}185 \cdot 2 \\
(41 \cdot 8) \\
\mathrm{n}=8\end{array}$ & $\begin{array}{c}480 \cdot 9 \\
(254 \cdot 5)\end{array}$ & $\begin{array}{c}400 \cdot 0 \\
(127 \cdot 8)\end{array}$ & $\begin{array}{c}35 \cdot 9 \\
(39 \cdot 3)\end{array}$ & $\begin{array}{c}34 \cdot 5 \\
(18 \cdot 4)\end{array}$ \\
\hline CD32 & $\begin{array}{l}128 \cdot 3 \\
(44 \cdot 0) \\
n=6\end{array}$ & $\begin{array}{l}182 \cdot 1 \\
(61 \cdot 9) \\
n=7\end{array}$ & $\begin{array}{c}575 \cdot 0 \\
(166 \cdot 8)\end{array}$ & $\begin{array}{c}633.6 \\
(363 \cdot 7)\end{array}$ & $\begin{array}{l}18 \cdot 16 \\
(9 \cdot 2)\end{array}$ & $\begin{array}{c}18 \cdot 71 \\
(13 \cdot 3)\end{array}$ \\
\hline
\end{tabular}

Values are mean $(\mathrm{SD})$.

${ }^{\star} \mathrm{p}=0.0007$ without antibody. These basal values did not differ significantly between patients and controls. There was, however, a small but significant increase in basal $\left[\mathrm{Ca}^{2+}\right]_{i}$ of cells from patients with RA compared with controls after incubation with CD16 antibody (mean basal value in controls $186 \mathrm{nmol} / \mathrm{l}$ and in RA patients $254 \mathrm{nmol} / \mathrm{l} ; \mathrm{p}=0.0007$ ) (fig $2 \mathrm{~A}, \mathrm{~B}$ ).

Addition of $F(a b) 2$ fragment of sheep antimouse IgG to neutrophils that had not been incubated with a primary monoclonal antibody had no effect on $\left[\mathrm{Ca}^{2+}\right]_{\mathrm{i}}$ (fig $1 \mathrm{~A}, \mathrm{E}$ ); we have shown previously that not all intact IgG antibodies to neutrophil surface antigens cause a change in $\left[\mathrm{Ca}^{2+}\right]_{\mathrm{i}}{ }^{12}$ When cells were preincubated with CD16, CD59, or CD32 antibodies, the addition of the cross linking second antibody resulted in a transient increase in $\left[\mathrm{Ca}^{2+}\right]_{\mathrm{i}}$ in all donors (figs 1,2 ). There was no significant difference in either the lag time or the peak $\left[\mathrm{Ca}^{2+}\right]_{\mathrm{i}}$ for any of the three antibodies between normal control subjects and patients with RA (table).

\section{Discussion}

The ability of neutrophils to signal correctly in the presence of external stimuli is an important facet in their armoury, which includes the phagocytosis of immune complexes and opsonised particles, and the production of reactive oxygen species and other effector molecules. Any abnormality in signalling could contribute to the pathogenesis of inflammatory diseases such as RA, and it has been shown previously that subtle but potentially important abnormalities do exist in the calcium signalling of neutrophils from patients with RA: after stimulation, the amount of the cell cytosol occupied by increased amounts of $\mathrm{Ca}^{2+}$ was significantly increased in RA blood and synovial fluid neutrophils compared with normal blood neutrophils, ${ }^{13}{ }^{14}$ while another report described a low basal concentration of $\left[\mathrm{Ca}^{2+}\right]_{\mathrm{i}}$ and low or no response to cross linking of either CD16 or CD32 on neutrophils from patients with active RA. ${ }^{9}$ Our present data strongly suggest that antibodies do not induce signalling by binding of the Fc portion of intact antibody to the Fc receptors, but bind via their $\mathrm{F}(\mathrm{ab})_{2}$ portions.

Our particular interest in complement regulation and inflammatory disease led us to examine whether cell activation, induced by cross linking the complement regulatory molecule CD59 and other GPI anchored molecules, was abnormal in active RA. In contrast to the report of Goulding and Guyre, ${ }^{9}$ our results demonstrate that blood neutrophils from patients with active RA show normal intracellular calcium changes in response to cross linking of the Fc receptors CD16 (GPI anchored) and CD32 (transmembrane), and of the GPI anchored complement regulatory protein, CD59. The reasons for the conflicting results are unclear, but there were several differences in methodology between the two studies. First, the neutrophils in our study were isolated using dextran and Histopaque-a method chosen to cause minimal cell activation-whereas Goulding and Guyre used a 
Ficoll meglumine M85 gradient method. Second, different monoclonal antibodies to CD16 and CD32 were used: the CD16 and CD32 antibodies used in our study were both IgG1 subclass, while the antibodies used by Goulding and Guyre (IV.3 to FcyRII and 3G8 to FcyRIII) were IgG2b and IgG2a, respectively. The antibodies used in both studies block the ligand binding activity of their respective FcR (confirmed for IV.3 and 3G8 by Mederex, and for MEM-154 by Dr V Horejsi, personal communication; reported by Greenman et al ${ }^{15}$ for AT10). Third, we labelled cells with monoclonal antibodies at $4^{\circ} \mathrm{C}$ rather than $37^{\circ} \mathrm{C}$ to prevent the internalisation or shedding that can occur at $37^{\circ} \mathrm{C}^{16}$ this may be significant if neutrophils from RA patients and normal control donors differ in their cell surface protein turnover. Fourth, we used fura-2 for measuring $\left[\mathrm{Ca}^{2+}\right]_{\mathrm{i}}$ because it can be used in a ratiometric way, alleviating the problems caused by background noise that cannot be addressed using indo- 1 in the non-ratiometric approach used by Goulding and Guyre. Our study thus does not support previously reported findings of reduced resting $\left[\mathrm{Ca}^{2+}\right]_{\mathrm{i}}$ and markedly reduced intracellular $\mathrm{Ca}^{2+}$ fluxes upon cross linking Fc $\gamma$ RII or Fc $\gamma$ RIII in RA neutrophils.

Three patients with RA showed a considerably greater increase in $\left[\mathrm{Ca}^{2+}\right]_{i}$ on cross linking CD16. However, these patients showed no distinctive clinical features, nor did this trend follow on cross linking CD32 or CD59.

Our finding of a small but significant increase in basal $\left[\mathrm{Ca}^{2+}\right]_{\mathrm{i}}$ in RA neutrophils after incubation with CD16 antibody in the absence of cross linking antibody suggests that this antibody may cause some activation in the RA neutrophils. We have previously shown that there is no difference in the surface expression of CD16 on blood neutrophils from normal controls and patients with active RA. ${ }^{17}$ It is unlikely, therefore, that the observed increase in basal $\left[\mathrm{Ca}^{2+}\right]_{i}$ in this study is related to differences in CD16 surface expression between the normal and RA patient group, while it may reflect 'priming' of RA neutrophils for response through CD16.

In conclusion, we found no difference in the signalling induced by cross linking CD16, CD32, or CD59 with secondary antibody in peripheral blood neutrophils in patients with active RA compared with neutrophils from control subjects. This suggests that, at least in vitro, peripheral blood neutrophils from patients with RA have a normal capacity to interact with immune complexes, producing an increase in intracellular calcium concentration.

We thank the Arthritis and Rheumatism Council for financial support through the award of a programme grant (C0091). We thank Dr Maurice Hallett for helpful discussion. B P Morgan is a Wellcome Senior Clinical Research Fellow.

1 Davies A, Simmons D L, Hale G, et al. CD59, an LY-6 like protein expressed in human lymphoid cells, regulates the action of the complement membrane attack complex on action of the complement membrane attack compl
homologous cells. $\mathcal{F} \operatorname{Exp}$ Med 1989; 170: 637-54.

2 Morgan B P, van den Berg C W, Davies E V, Hallett M B, Morgan B P, van den Berg C W, Davies E V, Hallett M B,
Horejsi V. Cross-linking of CD59 and of other glycosyl phosphatidylinositol-anchored molecules on neutrophils triggers cell activation via tyrosine kinase. Eur f Immunol 1993; 23: 2841-50.

3 Lund-Johansen F, Olweus J, Symington F W, et al. Activation of human monocytes and granulocytes by monoclonal antibodies to glycosylphosphatidylinositolanchored antigens. Eur f Immunol 1993; 23: 2782-91.

4 Kimberley R P, Ahlstom J W, Click M E, Edberg J. The glycosyl-phosphatidylinositol-linked Fc gamma RIII mediates transmembrane signaling events distinct from mediates transmembrane signaling events dis
Fc gamma RII. $\mathcal{E x p}$ Med 1990; 171: 1239-55.

5 Lund-Johansen F, Olweus J, Aarli A, Bjerknes R. The IgG FcRII and the PI-linked IgG FcRIII trigger cytoplasmic
Fctich calcium fluxes independently in human granulocytes. Scand F Immunol 1991; 33: 261-6.

6 Huizinga T W J, Dolman K M, Van der Linden N J M, et al. Phosphatidylinositol-linked FcRIII mediates exocytosis of neutrophil granule proteins, but does not mediate initiation of the respiratory burst. $f$ Immunol 1990; 144: 1432-7.

7 Hundt M, Schmidt R E. The glycosylphosphatidylinositollinked Fc receptor III represents the dominant receptor structure for immune complex activation of neutrophils. Eur f Immunol 1992; 22: 811-6.

Eur f Immunol 1992; 22: 811-6.
8 Brown K A. The polymorphonuclear cell in rheumatoid arthritis. Br $\mathcal{F}$ Rheumatol 1988; 27: 150-5.

9 Goulding N J, Guyre P M. Impairment of neutrophil Fc receptor mediated transmembrane signalling in active rheumatoid arthritis. Ann Rheum Dis 1992; 51: 594-9.

10 Morgan B P, Campbell A K. The recovery of human polymorphonuclear leucocytes from sublytic complement attack is mediated by changes in intracellular free calcium. Biochem $\mathcal{F}$ 1985; 231: 205-8.

11 Al-Mohanna F A, Hallett $M$ B. The use of fura-2 to determine the relationship between cytoplasmic free $\mathrm{Ca}^{2+}$ and oxidase activation in rat neutrophils. Cell Calcium 1988; 9: 17-26.

12 Morgan B P, van den Berg C W, Davies E V, Hallett M B, Horejsi V. Cross-linking of CD59 and of other glycosyl phosphatidyl inositol-anchored molecules on neutrophils phosphatidyl inositol-anchored molecules on neutrophils triggers cell activation

13 Davies E V, Campbell A K, Williams B D, Hallett M B. Single cell imaging reveals abnormal intracellular calcium signals within rheumatoid synovial neutrophils. $\mathrm{Br} \mathcal{f}$ Rheumatol 1991; 30: 443-8

14 Davies E V, Williams B D, Whiston R J, Cooper A M, Campbell A K, Hallett M B. Altered $\mathrm{Ca}^{2+}$ signalling in human neutrophils from inflammatory sites. Ann Rheum Dis 1994; 53: 446-9.

15 Greenman J, Tutt A L, George A J T, Pulford K A F, Stevenson G T, Glennie M J. Characterization of a new Stevenson G T, Glennie M J. Characterization of a new
monoclonal anti-FcyRII antibody, AT10, and its monoclonal anti-Fc $\gamma$ RII antibody, $A T 10$, and its
incorporation into a bispecific $F\left(a^{\prime}\right)_{2}$ derivative for incorporation into a bispecific $\mathrm{F}\left(\mathrm{ab}^{\prime}\right)_{2}$ derivative for
recruitment of cytotoxic effectors. Mol Immunol 1991; 28: 1243-54.

16 Huizinga T W J, Van der Schoot C E, Jost C E, et al. The PI-linked receptor FcRIII is released on stimulation of neutrophils. Nature 1988; 333: 667-9.

17 Jones J, Laffafian I, Cooper A M, Williams B D, Morgan B P. Expression of complement regulatory molecules and other surface markers on neutrophils from synovial fluid and blood of patients with rheumatoid arthritis. $B r \mathcal{F}$ Rheumatol 1994; 33: 707-12. 